\title{
An Assessment of the Role of Money in Nigerian General Election
}

\author{
AuwalAbubkar $\mathrm{Chul}^{1,}{ }^{1}$ MohdMahadee bin ismail ${ }^{2}, \mathrm{Ku}$ Hasnita Ku Samsu ${ }^{3}$ \\ Faculty Of Human Ecology, University Putra Malaysia Auwal Abubkar Chul
}

\begin{abstract}
This article is an attempt to assess the role of money in Nigerian election and political processes as a hindrance to strengthening democracy. Money is needed for democracy because much of its political activity simply could not occur without it. However, when discussing its costs and benefits one should know that the misuse of money in politics can create some major problems for a political regime. Vote buying denies a society the democratic principle of transparency and accountability because vote buyers are under no obligation to serve the masses interest. It discovered and argued that money in Nigeria politics' being an acceptable means of electoral financing, shifted to mild vote buying in the year 1960s during the second republic and later become pervasive and more widespread; especially since 1999 . The article concludes with recommendation of reforms, political education to the civil society and enforcement of election laws.
\end{abstract}

\section{INTRODUCTION}

Democracy entails the conception of election as the means of selecting political decision makers. Election is described as the pillar of democracy. Election is the back born of democracy and there is no democracy in the absent of election (Nnoli, O. 2006). Nigeria is a country with a long history of military rule while democracy is seen as the most desirable and best system of government. Election in Nigeria is characterized by multi-party system of politics and systematic institutional arrangement. An understanding of the system of Nigeria elections, it needs a synergy provided by the link against the background of the previous election in Nigeria. Money needed for democracy because much of its political activity simply could not take place without it. Money cannot be kept aside in the political process; campaigns cost money, as political office aspirants need funds to properly remunerate their staff. Fox pointed out that money is needed to prints brochures, pamphlets, radio and television adverts, renting space for campaign offices (Fox 2010).

However, when explaining its costs and benefits one should stress that the misuse of money in politics can create some major problems for a political regime. Nigeria has a history of poor governance characterized by corruption, social injustice and political instability. It discovered and argued that money in Nigeria politics' being an acceptable means of electoral financing, shifted to vote buying in the year 1960s during the second republic and later become pervasive and more wide domination; especially since 1999. However decades of military rule distorted democratic social values and undermine democratic institution. Corruption has become pervasive in all cycle of public and private lives.It is pertinent to observe that it is not in any way being suggested that the use of money by political parties, any person or group of persons in politics has inherent corruption influence (Davies 2006). The truth is that money is needed for sundry services and logistics such as mobilization for political campaigns and rallies, printing of posters and manifestoes, production of party emblems and other symbols etc. The only worry however, is the noticeable corrupting influence of money and vote buying in election and their negative impact on good governance in Nigeria.

\section{Conceptual clarification}

Election: Election: is represented as a process by which the electorates of a country vote directly to elect their leaders in either legislative or executive arm of government, or choice of selecting a leader by people vote. (Nnaemeka A.A, 2015). Democracy entails the notion of election as the means of selecting political decision makers. Election is described as the pillar of democracy. Election is the back born of democracy and there is no democracy without election (Nnoli, O. 2006).

Money politics: can be define as the event in the electoral process whereby the contenders for elective position use money as an inducement to mobilize and get support of the electorates which is not based on persuading the electorate to vote according to their whish and conviction but on the force of money that change their thinking (Ovwasa,2003). 


\section{Money and electoral process in Nigeria}

Money cannot be kept aside in the electoral and political process; campaigns cost money, as political office aspirants need funds to properly remunerate their staff. Fox pointed out that money is needed to prints brochures, pamphlets, radio and television adverts, renting space for campaign offices (Fox 2010). The nature of politics varies largely between various regions and nations, it is hardly contestable that there is nowhere in the globe where money is not needed in a political decision making process or in campaign process (Ohman, 2013). Further argued that money in politics has a significant nexus with key aspect of any modern state and he also noted that the management of political finance determines the credibility of elections and electoral campaigns of any nation or state. This in his opinion is so because money has the tendency to spoil completion between and among contestants.

Ohman(2013) furthermore stated that a democratic society must of necessity be characterized by ongoing dialogue with its citizens and this process requires funding. He noted further that the concern is that money has the capacity to make politicians more responsive to contributors than to the electorate. In view of the centrality of money to politics, he emphasized the need for controlling its impacts in order to drive it function to positives aspects, while keeping at bay its negative aspect and influences (Ohman, 2013).

Losing election in Nigeria means to be expelled from political life; the winner takes all, those who in elections do so at the expense of the losers. Once opponents, for whatever reasons, scuttle an individual chances they become completely irrelevant in the political process. He or she cannot contest an election again. It is against this backdrop that one works so hard to win election. When a candidate is sure of losing an election, follower's votes are traded for positions in the regime of the winners. Vote buying at the party or flag bearer level becomes one of the most accessible means of securing political relevance and participation. If negotiations fail to produce a workable bargain at this level, then violence take over. Looking at the dynamic use of money in politics, a growing academic interest in 'money in politics' in recent decades has produced a quiet number of works, the writing range from conceptual variation (Adetula,2008; Fontana,2007; Lucky,2013) to its manifestations (transparency international, 2004; ologbena and Adisa,2012) (walecki,2003;Pfeiffer,2003; Adetula,2008),etc. irrespective of the focus, however, the 'use of money' in politics has always constituted whole features of virtually all the electoral processes in the world over, primarily because of the undeniable worldwide convention of election finance as an essential component of democracy, even as it is frightening and disdainful (transparency international,2004; Amundsen,2006; Fontana,2007; Ologbenla and Adisa,2012;). Persons seeking political office deploy money to run electoral campaigns, offices and address pressure and other interest group, as well as foot advertising and legal costs, policy research and political education, lobby services, etc.

Similarly, Nigerian extant electoral statutes recognize spending by political office seekers. Sections 88 \& 91 of the electoral (amendment) Act 2010 has provided for election finance by presidential candidates, governors, national and state assemblies and chairmen of local government councils. Also, in the handbookofthe independent national electoral commission INEC (2005:25) has recognized election finance as an accepted principle, accepting that as the sophistication and complexity of communications and other technologies needed to effectively compete for votes increases for the vast resources by political parties to finance their electoral campaigns, more over in a recent study on political party financing from 1999; a respondent described the 'norm' in illegal election financing in Nigeria, thus, if you do not have money, you cannot be able to massively campaign through the media, you can hardly be able to buy guns or give bribe, no matter how acceptable your program is to public. Money plays an important role because of the corrupt nature of the election process in Nigeria politics which, in nearly all cases, is devoid of ethical conduct, (Wakili, zango and mohammed, 2008:62).

Unfortunately, unlike money use in electoral and political process of the advanced societies strictly within legal limits, Nigerian politics become excessively monetized, with widespread, often illegal and undetected use of money by politicians in elections taking the front burner, under guises such as 'dividends of democracy; 'votes buying' 'food or stomach politics' 'money bags' 'god father' etc. the legal regime funnel is full of holes, allowing politicians to refuse to keep, and disclose, full and accurate records of all election finances in accordance with the electoral (Amendment) Act 2011, and political finance and manual 2011. One obvious implication of the unbridled illegal use of money in elections, it's potential to undermine citizen's access to the political process, affording the rich and powerful individuals, corporations and big business the mechanism to wrest political influence out of the hands of the great majority. Since the restoration of civilian rule in 1999, attempts to strengthen the democracy through elections have been severely imperiled by a complex web of four broad categories of hindrances that either sprout at particular polls, or have persisted across all elections, to significantly block the processes. These include the transformation of money use in elections and the behavioral and attitudinal postures of voters and politicians, party organizational and strategic gaming, the political contexts of elections and weaknesses within election management body. In particular, Nigeria exceeds the usual bounds to monetized' political culture began as a pleasant 'use of money' in the 1960's and grew 
somewhat during the period of military rule. From 1999, its fallout has taken the form of widespread illegitimate use of money in elections, where political aspirants unhesitatingly deploy huge sums to buy electoral officers, oppositions party agents, security, the electorate etc. purchase of votes, unfortunately, take place using multiplicity of method. Some fallout of the "monetization of elections is to breed corruption in the entire political system and diminish the prospects of deepening democracy, primarily because it dampens the strengthening of citizen interest and faith in democracy. Such a possibility is fraught with obvious dangers.

Looking at the development of political party financing in Nigeria, the problem of unregulated use of money of money in politics did not begin today. They are antecedents in the history of modern Nigeria beginning with the politics of nationalism in the 1950s, similar to rent seizing behaviors of parties, politicians and voters. The absence to regulate party financing made it possible for politicians and political parties to engage in illegal party financing and corruption in Nigeria during first republic. During this period there was no clearly defined regulatory framework on party finance and political party funding was primarily carried out through privates since candidates were responsible for election expenses.

\section{Monetization of election in the fourth republic to date in Nigeria}

The large majority of Nigeria's uncontrollably growing population has continued to roll in increasing pain, occasioned by poverty flourishing in the midst of plenty. With the return of democracy 1999 election primarily intended to make the transition to civil rule in the country, fear and hesitation surrounding the uncertainty about the true of the military severely limited the excess use of money by the politicians of the first set of fourth republic.

One of the few early omen signs of monetization of the electoral and political process occurred during or in the first civilian to civilian transition in 2003. At the re-election fund raising organized by the then ruling party, people Democratic Party (PDP) ahead of the polls, under the leadership of chief olusegunobasanjo and AtikuAbubakar, president and vice president respectively, were widely criticized for reportedly collected between two billion and three billion naira as campaign contributions with two individuals, "AlikoDangote and EmekaOffor donated one billion naira and other undisclosed huge amount of money donated by the Nigerian port Authority (NPA). (Weekly trust, March 8, 2003). More so all federal cabinet ministers donated the sum of ten million naira; PDP state governors donated two hundred and ten million naira, (The guardian, February 25, 2003).This led to concluded that "voters have got bags and boxes of money, cars, motorcycle etc with critics saying that voters have exchange their rights to social services such as education, good road, hospital, electricity, good schools and portable drinking water for money, bags of rice and salt (Weekly trust, may 3-9, 2003). Money politics has first found acceptance in the fourth republic from 2003 on the party sanctioned cost of buying forms for the expression of interest, as well as to actually contest in the primary election in respect to all posts. In recent during the preparation of 2015 elections, the NEC of APC met September 30, 2014 and decided to increase the costs of the forms amounts ranging from \#2 million to \#27.5, also PDP, also charged between \#2 million to \#20 million. (Daily trust, November 13, 2014). Entirely party affairs, some aspirants launched a persistent singing criticizing the decision, perceiving it as deliberately intended to edge out those financially weak among them (BBC Hausa service, October 23, 2014). Therefore many party supporters regarded it as a design to pave way for money bags and political god-fathers to hijack the electoral and political processes in order to install their 'boys'. The 2015 APC Presidential candidateMuhammadBuhari, complained bitterly of having to secure an overdraft from his bank manager to pay the charges. In the fourth republic on the campaign pathway, the immediate needs of the electorates an expected to meet at any community occasion, such as naming, wedding ceremony, students gathering, also include money, food items assistance, etc.Politicians adopted various means of giving money and other gifts in kind to change the moral sense of the electorate. A political party or candidate may directly or indirectly bribe voters and election officials. They may in a possible way offer the electorate different kinds of incentives (gifts, food, alcohol, or even short-term employment). This is what we call 'stomach infrastructure'. Politicians send advance team who will go from place to place to distribute items such as maggi, salt, sugar, clothes, money and other items to electorates during campaigns or voting.

\section{Implication of the Monetization of Elections in Nigeria}

The fourth republic democracy in Nigeria began with the restoration of civil rule in 1999 attempt to strengthen the present of democracy through elections have been severely imperiled by a complex web of issues that hinders polls across all elections to significantly block the processes, these includes, vote buying denies a society the democratic principle of transparency and accountability because vote buyers are under no circumstances to serve the masses interest. Buying and selling of votes is only a form of political venture where investment comes from the former party. As argue by Danjibo and Oladeji (2007), money politics make politicians to see themselves as investing in a greater political harvest, thereby encouraging the entrenchment of corruption in the polity which does away the very basis of democratic governance. Where candidates have 
invested much before being elected or appointed into public office, simple economic rationality will propel them to make the money they have invested in as many folds as possible. Where that is the case, accountability and transparency known to be hallmark of good governance and democracy becomes jettisoned to the detriment of the system (Ojo, 2008).

It also promotes elitist and capitalist politics and weakens people participation. This according to Dung will only place persons with the resources to get access to political offices in Nigeria and will discourage the vulgar or masses from political leadership due to their financial incapability (Dung Pam, 2008). In essence political affairs become monetized. However, monopoly of power by the financial strong political party can be ensured. This act has weakened the image of our political system outside Nigeria's boundary. Within the international system, Nigeria politicians do not enjoy integrity. The political institutions in the country lack democratic virtues. This situation has ultimately been creating a devastating impact on the legitimacy of Nigerian electoral and political processes. Be this as it may, politics of money may engineer another military intervention due to legitimacy crisis being suffered by the present administration. In a situation whereby dividends of democracy are not achievable; military can have such opportunity to hijack or seize the political system. Even some Nigerians are clamoring for military rule due to the disappointment witnessed from the civilian government. Comparatively, some have rated military regime higher than their counterpart, civilian government. Though military rule is not a solution to civilian flaws, attitudinal change would place Nigeria's leader's right

\section{RECOMMENDATIONS}

It will be hard money politics and vote-buying can be totally eradicated in Nigeria. However, there should be at least some control measure by which its negative consequences on credible elections can be minimized. The study recommends that it is of primary importance to first and foremost call on all stakeholders in the Nigerian project for state of mind or attitudinal changes so as to have positive perception of politics. This is because a system of free and fair election is not guaranteed by officially sanctioned legal instrument alone. On the side of the people, they should shun those politicians who play dirty game and money politics, knowing well that the money belongs to them, but being often siphoned by the corrupt politicians. Again, political parties should abstain from projecting the financial reputation of the wealthy candidates and their financial quality to the parties. This is because such candidates have the tendency to act and to live up to the image so created by injecting money into the campaign than is morally justified there by siphoning the government money main for development. More transparent and effective screening methods must be developed by the political parties and the electoral body, to ensure the exclusion of credible candidates and politicians who are not corrupt within the electoral process and the electorate. There is also need for political education of the electorate to be better in their electoral choices, and minimize the pressures put on their elected representatives for financial and material gain and prize for vote.Party officials should be trained on how to manage electioneering process and campaigns in which candidates have a well and effective manifestoes. Unlike in the second republic when major political parties clearly articulated their fundamental importance programs, the case is different in the fourth republic where voters are as confused as the politicians. Also the government with the use of the mass media has a cardinal role to play in educating and enlighten voters to know their primary responsibilities in electing credible candidates. For instance, where the media is celebrating money-bags, who are using their wealth to undermine the democratic process, credible elections and good governance, the appearance of money politics and votebuying will continue to increase in Nigerian electoral and political system. It is appeared that poor people are candidates of votes selling in a situation whereby the masses are better off in terms of standard of living; voters would not be easily go for such unconstitutional act. The government should create employment for the teeming youths and ensure enabling environment for economic growth. The act of collecting bribe and selling one's electoral mandate is not only immoral but also harmful to the development of the country. Basically, poverty usually serves as an obstacle to democracy.

\section{CONCLUSION}

Nigeria seems to be at crossroads as 2019 is around the corner, due to the increasing anxiety and difficult task ahead of the general elections. The work has carefully and critically analyzed the main issues and challenges of money politics and vote buying as it affects the credibility of elections, the work concluded that if the strategies suggested in the work are taken seriously and implemented, Nigeria can make and conducting free, fair and credible elections without money politics, vote buying, stomach infrastructure. 


\section{REFERENCES}

[1]. Adetula, A.O. (2008), Money and politics in Nigeria, Abuja petra Digital Press.

[2]. Ake C. (2001), Democracy and development in Africa Ibadan. Spectrum publishers.

[3]. Alabi, M. O. (2008) "The Electoral Act 2006 and the Conduct of 2007 Election in Nigeria"

in H. A. Saliu et al (editors) Niger ia Beyond 2007: Issues, Perspectives and Challenges: Faculty of Business and Social Sciences, University of Ilorin, Ilorin.

[4]. Albert, I. O. (2012), Deconstructing Elite Fragmentation in Nigeria politics. In Ibadan journal of Peace and Development, A Publication of peace and conflict studies Programmed,Instituteof Africa studiesIbadan.

[5]. Davies, A. E. (2006)"Money AndPolitics in the Nigeria Electoral Process: A Memo of Department of Political Science, University of Ilorin - Ilorin.

[6]. Fox, J. W. (2010). The role of money in campaign politics, the legacy journal, (online).

[7]. Restoreamericanlegacy.com/the legacy journal//. (Acessed 2, October 2016).

[8]. Nnoli, O. (2006), Introduction to politics. Enugu fourth dimension.

[9]. Obasanjo O. (2005) Political Party Finance Handbook Independent Electoral Commission Obasanjo O. (2005) Political Party Finance Handbook Independent Electoral Commission (INEC) Abuja.

[10]. Ohman, M. (2013).Controlling money in politics. An introduction, speech for international Foundation For electoral system (IFES) Washington D. C.

[11]. http://en.wikipedia.org/wikirational/ifes.online Ojo, E. O. 'Vote-Buying in Nigeria' Money Politics and Corruption in Nigeria: UK Department For International Development (DFLD) "Nigeria Election Support 2007 Programme.

[12]. Ologbenla, D. and Adisa, W.B (2012), Money-bags politics, rent seeking and flawed election in Nigeria.

[13]. Ovwasa, O. L. (2013), Money Politics and Vote Buying in Nigeria: The Bane of Good

[14]. Govevrnance.Afro Asian Journal of Social Science. Vol.4 No 4.3

[15]. Weekly Trust 2003.

[16]. Daily Trust 2014. 